\title{
Soybean Meal Can Be Replaced by Faba Beans, Pumpkin Seed Cake, Spirulina or Be Completely Omitted in a Forage-Based Diet for Fattening Bulls to Achieve Comparable Performance, Carcass and Meat Quality
}

\author{
Magdalena Keller ${ }^{1}$, Beat Reidy ${ }^{2}$, Andreas Scheurer ${ }^{2}$, Lukas Eggerschwiler ${ }^{3} \mathbb{D}$, Isabelle Morel $^{3}$ \\ and Katrin Giller ${ }^{1, *(\mathbb{D})}$ \\ 1 ETH Zurich, Institute of Agricultural Sciences, Universitaetstrasse 2, 8092 Zurich, Switzerland; \\ magdalena.keller@usys.ethz.ch \\ 2 School of Agricultural, Forest and Food Sciences HAFL, Bern University of Applied Sciences, \\ 3052 Zollikofen, Switzerland; beat.reidy@bfh.ch (B.R.); andreas.scheurer@bfh.ch (A.S.) \\ 3 Agroscope, Route de la Tioleyre 4, 1725 Posieux, Switzerland; \\ lukas.eggerschwiler@agroscope.admin.ch (L.E.); isabelle.morel@agroscope.admin.ch (I.M.) \\ * Correspondence: katrin.giller@usys.ethz.ch; Tel.: +41-44-632-2561
}

check for updates

Citation: Keller, M.; Reidy, B.; Scheurer, A.; Eggerschwiler, L.; Morel, I.; Giller, K. Soybean Meal Can Be Replaced by Faba Beans, Pumpkin Seed Cake, Spirulina or Be Completely Omitted in a

Forage-Based Diet for Fattening Bulls to Achieve Comparable Performance, Carcass and Meat Quality. Animals 2021, 11, 1588. https://doi.org/ $10.3390 /$ ani11061588

Academic Editors: Sandra Lobón and Margalida Joy

Received: 15 March 2021

Accepted: 22 May 2021

Published: 28 May 2021

Publisher's Note: MDPI stays neutral with regard to jurisdictional claims in published maps and institutional affiliations.

Copyright: (c) 2021 by the authors. Licensee MDPI, Basel, Switzerland. This article is an open access article distributed under the terms and conditions of the Creative Commons Attribution (CC BY) license (https:// creativecommons.org/licenses/by/ $4.0 /)$.
Simple Summary: The sustainability of intensive beef production systems can be greatly improved using domestic protein sources as alternatives to imported soybean meal. Potential alternatives include indigenous grain legumes such as faba beans, food industry by-products including locally available oil cakes, or novel protein sources such as microalgae. Moreover, diets based on grassland-derived feeds increase dietary protein supply and have the potential to enhance food system sustainability. This study aimed to assess the effects on fattening performance, carcass and meat quality, and the meat fatty acid profile of beef cattle when replacing, or omitting, soybean meal in the diet. Bulls fed a grass/maize-silage based diet supplemented with concentrate containing either soybean meal, faba beans, pumpkin seed cake, or spirulina had similar growth performances and carcass and meat quality. No differences were observed in the meat fatty acid profiles. Most notably, omitting soybean meal without additional protein-concentrate replacements resulted in comparable carcass and meat quality without affecting the meat fatty acid profile while maintaining a high-performance level. Consequently, the grass silage-based diet supplemented with a grain-based concentrate without additional protein source was the most sustainable diet for growing bulls tested in this study.

Abstract: The aim of the study was to investigate the complete substitution of imported soybean meal in beef cattle diets and the consequences on performance, meat, and adipose tissue quality. Thirty growing crossbred Limousin bulls, with an initial bodyweight of $164 \pm 13 \mathrm{~kg}$ and $4.3 \pm 0.3$ months of age, were fed a grass/maize-silage based diet with little additional concentrate (0.5:0.3:0.2) Concentrates contained either soybean meal (positive control), faba beans, pumpkin seed cake, or spirulina (Arthrospira platensis), resulting in about $226 \mathrm{~g}$ crude protein $(\mathrm{CP}) / \mathrm{kg}$ concentrate dry matter (DM) and $158 \mathrm{~g} \mathrm{CP} / \mathrm{kg}$ total diet DM. A grain-based concentrate providing just $135 \mathrm{~g} \mathrm{CP} / \mathrm{kg}$ concentrate DM and $139 \mathrm{~g} \mathrm{CP} /$ total diet DM served as a negative control. Bulls of all groups had comparable average daily gains $(1.43 \pm 0.1 \mathrm{~kg})$ and feed intakes $(6.92 \pm 0.37 \mathrm{~kg})$. Carcass and meat quality did not differ among groups. The fatty acid profile of meat lipids was hardly affected. These results indicate that soybean meal can be replaced by any of the tested protein sources without impairing performance or meat quality. Importantly, bulls fed the negative control achieved a fattening and slaughter performance comparable to that of the protein-supplemented groups without affecting meat and adipose tissue quality. Thus, the present findings suggest that feeding crossbred bulls a grass/maize-silage based diet does not require additional protein supplementation.

Keywords: beef cattle; alternative protein sources; fatty acids; grass silage; sustainable production systems; microalgae 


\section{Introduction}

Intensive beef production in Europe relies heavily on maize silage and large amounts of concentrate to achieve high average daily gains (ADG) and a desirable carcass quality. While these diets are rich in energy and starch, they necessitate the addition of extra protein to meet dietary requirements of beef cattle. Protein requirements, particularly those of metabolizable protein, are traditionally met by the concentrate portion of the diet. In Swiss intensive beef production, concentrate proportions amount to almost one third of the total diet on a dry matter (DM) basis (300 g/ kg DM) [1]. Imported soybean meal (SBM) is often used as the main protein source for beef cattle as it is widely available and richer in valuable rumen undegradable protein (RUP) than most other protein sources. However, soy cultivation is increasingly controversial due to its negative environmental impacts (e.g., monocropping, loss of biodiversity and natural habitats, long transport routes, and high input requirements including land, fertilizers, and fuel) and poor socioeconomics (e.g., rural depopulation, loss of employment due to high levels of mechanization and agrarian transformation) $[2,3]$.

In contrast, grassland-derived feeds, that increase protein supply when included as part of the basal diet, are rarely used due to their comparably lower energy contents and a perceived lower animal performance $[4,5]$. Previous findings indicate that no additional protein may be required when feeding high-quality grass silage to growing bulls supplemented with barley-based concentrates to maintain performance, carcass, and meat quality [6-8]. However, average body weight (BW) gain was rather low (1.05 kg per day), whereas the dietary concentrate proportions applied were fairly high (300-700 g/ kg DM) $[6,7,9]$. Limiting the dietary concentrate proportion might increase production responses to protein supplements $[8,10]$. Therefore, when aiming for a high growth performance with $\mathrm{ADG}>1.30 \mathrm{~kg}$ during limited concentrate and high forage supply, sources specifically providing metabolizable protein are likely required due to the typically high ruminal protein degradability (RPD) of grassland-derived feeds.

Promising protein sources as alternatives to imported SBM include other grain legumes such as faba beans (Vicia faba). They can be grown globally [11,12] and improve the sustainability of cropping systems by preserving soil fertility and introducing beneficial pre-crop effects $[12,13]$. The high crude protein (CP) and starch contents as well as the high RPD of the faba bean make it a suitable protein source for cattle, particularly when combined with low-protein forages like maize silage [14-16]. However, the effects of faba beans as a replacement for SBM in grass-silage based diets for beef cattle have not yet been investigated.

Aside from grain legumes, locally available oil cakes present an interesting alternative protein source for the replacement of SBM in beef cattle diets. In comparison to rather common rapeseed and sunflower oil cakes, pumpkin seed cake has an outstandingly high $\mathrm{CP}$ content, around $600 \mathrm{~g} / \mathrm{kg}$ DM [17]. However, information about its nutritional value and suitability for beef cattle diets is scarce. Antunović, et al. [18] and Klir et al. [19] published the first promising results in lambs and dairy goats, respectively.

A third protein source that may be an interesting alternative to SBM are protein-rich microalgae such as spirulina (Arthrospira platensis, $730 \mathrm{~g} \mathrm{CP} / \mathrm{kg}$ DM [20]). Phototrophic spirulina can be cultivated in open ponds or closed photo bioreactors [21] on non-arable land such as rooftops [22] and at a high water-use efficiency [23]. When compared to soybean and rapeseed, spirulina provides a protein yield 15 to 20 times greater per unit area $[23,24]$. Due to these properties, spirulina has gained an interest as a protein replacement for SBM in cattle diets. However, previous studies investigating the use of spirulina as a dietary bovine protein source have focused on dairy cattle [25-27], while data on beef cattle are missing. The relatively high proportion of the somewhat rare fatty acid (FA), C18:3 $n-6$ ( $\gamma$-linolenic acid), in spirulina may yield a meat FA profile different to that of SBM fed animals, which has not yet been investigated in beef cattle. To our knowledge, comparisons of these protein sources in beef cattle fed a grass/maize-silage based diet have not been published. 
Therefore, the aim of this study was to investigate the effects of a complete replacement of SBM by faba beans, pumpkin seed cake, and spirulina, or its omission, on animal performance, meat, and adipose tissue quality in beef cattle fed a high proportion of grass silage accompanied by a limited amount of concentrate ( $200 \mathrm{~g} / \mathrm{kg}$ total diet DM). The following hypotheses were tested: (i) Some or all of these protein sources can replace SBM without adverse effects on growth and slaughter performance. (ii) The diet without additional protein sources impairs animal performance due to insufficient metabolizable protein supply. (iii) Replacing SBM does not affect meat quality. (iv) The intake of spirulina with its characteristic FA profile compared to the other protein sources results in a specific meat FA profile.

\section{Animals, Materials, and Methods}

\subsection{Animals and Diets}

The experiment was conducted at the AgroVet-Strickhof research station (Lindau, Switzerland) and was approved by the Cantonal Veterinary office of Zurich, Switzerland (license no. ZH129/18). It comprised five diets differing in concentrate protein source. The positive control (diet SB) contained solvent extracted SBM (Landi, Sense-Düdingen, Switzerland), which was replaced by either faba beans (fenaco Genossenschaft, Getreide, Ölsaaten, Futtermittel, Berne, Switzerland; diet FB), cold pressed pumpkin seed cake (Ölmühle Garting, Schnaitsee, Germany; diet PS) or the microalga, spirulina (Institut für Getreideverarbeitung, Nuthetal, Germany; diet SP) (Table 1). A concentrate with no additional protein source (diet NP) served as a negative control. The concentrates PS and NP were pelleted, while the concentrates SB, FB and SP were provided as meal due to unexpected technical problems in the pelleting process.

Table 1. Chemical composition and selected fatty acids (FA) of tested protein sources.

\begin{tabular}{|c|c|c|c|c|}
\hline Protein Source & Soybean Meal & Faba Beans & Pumpkin Seed Cake & Spirulina \\
\hline \multicolumn{5}{|c|}{ Proximate contents (g/kg DM) } \\
\hline DM (g/kg wet weight) & 882 & 864 & 925 & 945 \\
\hline Organic matter & 932 & 954 & 889 & 917 \\
\hline Crude protein & 536 & 275 & 623 & 710 \\
\hline Ether extract & 16.1 & 21.6 & 90.1 & 67.6 \\
\hline Neutral detergent fiber & 131 & 398 & 139 & n.a. \\
\hline Acid detergent fiber & 94 & 198 & 111 & n.a. \\
\hline Gross energy (MJ/kg DM) & 19.6 & 18.5 & 20.7 & 22.1 \\
\hline \multicolumn{5}{|c|}{ Crude protein fractions $(\mathrm{g} / 100 \mathrm{~g} \text { crude protein })^{1}$} \\
\hline $\mathrm{A}$ & 8.3 & 25.1 & 10.1 & 9.4 \\
\hline $\mathrm{B}_{1}$ & 6.5 & 43.6 & 19.6 & \\
\hline $\mathrm{B}_{2}$ & 82.1 & 17.5 & 68.7 & \\
\hline $\mathrm{B}_{3}$ & 2.5 & 12.5 & 1.1 & 91.6 \\
\hline $\mathrm{C}$ & 0.74 & 1.20 & 0.68 & \\
\hline \multicolumn{5}{|l|}{ FA $(g / 100 \mathrm{~g}$ total FA) } \\
\hline $\mathrm{C} 12: 0$ & 0.12 & 2.46 & 0.02 & 0.17 \\
\hline C14:0 & 0.16 & 0.69 & 0.12 & 0.11 \\
\hline C16:0 & 15.6 & 13.5 & 13.2 & 44.4 \\
\hline $\mathrm{C} 16$ iso & 0.05 & 0.09 & 0.03 & 1.43 \\
\hline $\mathrm{C} 16: 1 n-7$ & 0.15 & 0.39 & 0.15 & 3.37 \\
\hline C17:0 & 0.16 & 0.16 & 0.05 & 0.13 \\
\hline C16:2 & 0.00 & 0.00 & 0.00 & 0.31 \\
\hline C17:1 & 0.07 & 0.04 & 0.02 & 0.16 \\
\hline C18:0 & 3.96 & 2.76 & 4.95 & 1.05 \\
\hline C16:4 & 0.00 & 0.00 & 0.00 & 0.24 \\
\hline C18:1 trans -11 & 0.00 & 0.00 & 0.00 & 0.00 \\
\hline C18:1 cis-9 & 18.7 & 28.5 & 29.60 & 1.68 \\
\hline $\mathrm{C} 18: 1$ cis-11 & 1.79 & 0.36 & 0.82 & 0.31 \\
\hline C18:1 cis-12 & 0.00 & 0.00 & 0.00 & 0.00 \\
\hline $\mathrm{C} 18: 2 n-6$ cis & 51.0 & 45.0 & 49.0 & 18.6 \\
\hline
\end{tabular}


Table 1. Cont.

\begin{tabular}{ccccc}
\hline Protein Source & Soybean Meal & Faba Beans & Pumpkin Seed Cake & Spirulina \\
\hline C18:3n-6 & 0.00 & 0.04 & 0.00 & 26.66 \\
C18:3n-3 & 6.37 & 2.95 & 0.63 & 0.05 \\
C20:0 & 0.29 & 1.05 & 0.39 & 0.06 \\
C20:1 $n-9$ & 0.23 & 0.51 & 0.11 & 0.06 \\
C20:2 $n-6$ & 0.07 & 0.11 & 0.08 & 0.25 \\
C20:4 $n-6$ & 0.00 & 0.00 & 0.00 & 0.07 \\
C22:0 & 0.35 & 0.43 & 0.18 & 0.00 \\
C20:5 n-3 & 0.06 & 0.04 & 0.09 & 0.03 \\
C23:0 & 0.11 & 0.12 & 0.06 & 0.00 \\
C22:2 & 0.19 & 0.06 & 0.15 & 0.03 \\
C24:0 & 0.23 & 0.21 & 19.2 & 47.6 \\
$\sum$ Saturated FA & 21.2 & 21.8 & 30.8 & 5.9 \\
$\sum$ Monounsaturated FA & 21.1 & 30.0 & 50.0 & 46.5 \\
$\sum$ Polyunsaturated FA & 57.7 & 48.2 & 0.73 & 0.08 \\
$\sum n-3$ & 6.43 & 2.99 & 49.1 & 45.9
\end{tabular}

DM: dry matter; n.a.: not analyzed; ${ }^{1}$ A: non-protein nitrogen (NPN); $B_{1}$ : true soluble protein; $B_{2}$ : neutral detergent (ND) soluble protein; $\mathrm{B}_{3}$ : ND insoluble true protein, soluble in acid detergent (AD), C: insoluble in AD.

The positive control diet was designed according to the Swiss feeding recommendation for beef cattle with an ADG of $1.30 \mathrm{~kg}$ [28]. Based on this calculation, the concentrates containing the tested protein sources were calculated to provide a target $\mathrm{CP}$ content of $230 \mathrm{~g} / \mathrm{kg}$ DM by combining the protein sources with varying amounts of wheat, maize grain, wheat bran, molasses, and animal fat (Table 2). However, the requirements for metabolizable protein, particularly for metabolizable protein deriving from ruminal available energy (APDE) were deficient by 28,23 , and $18 \%$ in the early fattening period of 150,200 , and $250 \mathrm{~kg}$ BW, respectively. The target CP content for the NP diet was intended to be $130 \mathrm{~g} \mathrm{CP} / \mathrm{kg} \mathrm{DM}$.

Table 2. Components of the experimental concentrates, chemical composition and selected fatty acids (FA) of concentrates and forages.

\begin{tabular}{|c|c|c|c|c|c|c|c|c|c|}
\hline \multirow{2}{*}{ Feed } & \multicolumn{2}{|c|}{ Grass Silage } & \multicolumn{2}{|c|}{ Maize Silage } & \multicolumn{5}{|c|}{ Concentrates } \\
\hline & $1-26^{1}$ & $27-40^{1}$ & $1-10^{1}$ & $11-40^{1}$ & SB & FB & PS & SP & NP \\
\hline$n$ & 10 & 5 & 2 & 9 & 3 & 3 & 3 & 3 & 3 \\
\hline \multicolumn{10}{|l|}{ Ingredients (g/kg DM) } \\
\hline Soybean meal & & & & & 277 & - & - & - & - \\
\hline Faba beans & & & & & - & 748 & - & - & - \\
\hline Pumpkin seed cake & & & & & - & - & 227 & - & - \\
\hline Spirulina powder & & & & & - & - & - & 198 & - \\
\hline Wheat grain & & & & & 450 & 171 & 500 & 516 & 450 \\
\hline Maize grain & & & & & 237 & 45 & 248 & 250 & 225 \\
\hline Wheat bran & & & & & 11 & - & - & - & 300 \\
\hline Molasses & & & & & 20 & 20 & 20 & 20 & 20 \\
\hline Tallow-lard mixture & & & & & 5 & 16 & 5 & 16 & 5 \\
\hline \multicolumn{10}{|l|}{ Proximate contents (g/kg DM) } \\
\hline $\mathrm{DM}$ (g/kg wet weight) & 360 & 558 & 397 & 318 & 882 & 870 & 882 & 881 & 878 \\
\hline Organic matter & 864 & 876 & 966 & 962 & 968 & 964 & 961 & 971 & 967 \\
\hline Crude protein & 183 & 168 & 69 & 81 & 228 & 238 & 225 & 214 & 135 \\
\hline Ether extract & 37.0 & 26.1 & 31.3 & 29.4 & 26.0 & 31.4 & 48.6 & 47.4 & 34.7 \\
\hline Neutral detergent fiber & 477 & 512 & 414 & 471 & 464 & 473 & 459 & n.a. & 461 \\
\hline Acid detergent fiber & 344 & 333 & 270 & 311 & 105 & 137 & 93 & n.a. & 128 \\
\hline Acid detergent lignin & 50.2 & 56.4 & 44.2 & 39.5 & n.a. & n.a. & n.a. & n.a. & n.a. \\
\hline Gross energy (MJ/kg DM) & 17.6 & 17.9 & 18.2 & 18.4 & 18.6 & 18.5 & 18.8 & 19.0 & 18.4 \\
\hline Metabolizable energy (MJ/ kg DM) & 8.3 & 7.8 & 10.3 & 10.0 & 13.5 & 12.5 & 13.5 & 13.3 & 12.8 \\
\hline $\mathrm{APDE}(\mathrm{g} / \mathrm{kg} \mathrm{DM})$ & 67 & 78 & 61 & 62 & 155 & 109 & -2 & -2 & 105 \\
\hline $\mathrm{APDN}(\mathrm{g} / \mathrm{kg} \mathrm{DM})$ & 115 & 80 & 41 & 50 & 171 & 153 & -2 & -2 & 94 \\
\hline
\end{tabular}


Table 2. Cont.

\begin{tabular}{|c|c|c|c|c|c|c|c|c|c|}
\hline \multirow{2}{*}{ Feed } & \multicolumn{2}{|c|}{ Grass Silage } & \multicolumn{2}{|c|}{ Maize Silage } & \multicolumn{5}{|c|}{ Concentrates } \\
\hline & $1-26^{1}$ & $27-40^{1}$ & $1-10^{1}$ & $11-40^{1}$ & SB & FB & PS & SP & NP \\
\hline \multicolumn{10}{|l|}{ FA (g/100 g total FA) } \\
\hline$n$ & 3 & 3 & 2 & 3 & 2 & 2 & 2 & 2 & 2 \\
\hline C14:0 & 0.66 & 0.50 & 0.18 & 0.22 & 0.55 & 1.35 & 0.49 & 1.02 & 0.50 \\
\hline C16:0 & 15.0 & 16.2 & 13.2 & 13.1 & 16.6 & 19.7 & 15.7 & 24.6 & 16.6 \\
\hline $\mathrm{C} 16: 0$ iso & 1.96 & 1.85 & 0.13 & 0.17 & 0.09 & 0.14 & 0.06 & 0.37 & 0.11 \\
\hline C16:1 n-7 & 0.23 & 0.22 & 0.17 & 0.18 & 0.56 & 1.30 & 0.49 & 1.62 & 0.52 \\
\hline C17:0 & 0.14 & 0.16 & 0.11 & 0.13 & 0.22 & 0.46 & 0.18 & 0.36 & 0.21 \\
\hline C18:0 & 1.15 & 1.43 & 2.11 & 2.04 & 4.77 & 9.54 & 5.40 & 7.23 & 3.98 \\
\hline C18:1 trans-11 & 0.00 & 0.00 & 0.00 & 0.00 & 0.19 & 0.50 & 0.16 & 0.39 & 0.17 \\
\hline C18:1 cis-9 & 1.8 & 2.4 & 24.6 & 23.9 & 24.9 & 30.8 & 27.6 & 23.2 & 22.9 \\
\hline C18:1 cis-11 & 0.43 & 0.40 & 0.64 & 0.66 & 1.07 & 1.04 & 0.96 & 1.00 & 0.95 \\
\hline C18:1 cis-12 & 0.00 & 0.00 & 0.00 & 0.00 & 0.03 & 0.06 & 0.02 & 0.04 & 0.02 \\
\hline C18:2 n-6 cis & 13.2 & 15.1 & 52.4 & 50.0 & 45.8 & 29.6 & 45.0 & 32.3 & 48.5 \\
\hline C18:3 n-6 & 0.23 & 0.14 & 0.04 & 0.05 & 0.02 & 0.03 & 0.02 & 2.52 & 0.03 \\
\hline C18:3n-3 & 61.2 & 57.9 & 3.4 & 6.7 & 2.8 & 2.0 & 1.6 & 2.6 & 3.0 \\
\hline C20:0 & 0.36 & 0.57 & 0.61 & 0.51 & 0.29 & 0.57 & 0.33 & 0.23 & 0.25 \\
\hline C20:1 n-9 & 0.36 & 0.22 & 0.31 & 0.37 & 0.45 & 0.49 & 0.33 & 0.39 & 0.54 \\
\hline C20:4n-6 & 0.00 & 0.00 & 0.00 & 0.00 & 0.02 & 0.03 & 0.01 & 0.03 & 0.02 \\
\hline C22:0 & 0.78 & 0.72 & 0.36 & 0.32 & 0.18 & 0.23 & 0.16 & 0.10 & 0.16 \\
\hline C20:5 n-3 & 0.04 & 0.09 & 0.11 & 0.06 & 0.04 & 0.02 & 0.12 & 0.10 & 0.10 \\
\hline C24:0 & 0.66 & 0.60 & 0.50 & 0.52 & 0.17 & 0.13 & 0.15 & 0.10 & 0.17 \\
\hline$\sum$ Saturated FA & 21.4 & 22.8 & 17.5 & 17.5 & 23.2 & 32.7 & 22.8 & 34.3 & 22.2 \\
\hline$\sum$ Monounsaturated FA & 3.6 & 3.8 & 26.3 & 25.5 & 28.0 & 35.5 & 30.2 & 27.8 & 25.9 \\
\hline$\sum$ Polyunsaturated FA & 75.0 & 73.4 & 56.3 & 57.0 & 48.8 & 31.8 & 47.0 & 37.9 & 51.9 \\
\hline$\sum n-3 \mathrm{FA}$ & 61.4 & 58.0 & 3.6 & 6.8 & 2.8 & 2.0 & 1.7 & 2.7 & 3.1 \\
\hline$\sum n-6$ FA & 13.6 & 15.3 & 52.5 & 50.1 & 45.9 & 29.8 & 45.1 & 35.0 & 48.7 \\
\hline$n-6 / n-3$ FA & 0.2 & 0.3 & 14.6 & 7.4 & 16.4 & 14.9 & 26.5 & 13.0 & 15.7 \\
\hline
\end{tabular}

APDE: metabolizable protein derived from ruminal available energy; APDN: metabolizable protein derived from ruminal protein fermentation; DM: dry matter; FB: faba beans; GS: grass silage; MS: maize silage; n.a.: not analyzed; NP: no additional protein source; PS: pumpkin seed cake; SB: soybean meal; SP: spirulina. ${ }^{1}$ Periods of experimental weeks fed. ${ }^{2}$ metabolizable protein content of pumpkin seed cake and spirulina unknown.

Thirty Limousin-sired crossbred bulls (dams: Brown Swiss, 14; Holstein, 5; Swiss Fleckvieh, 5; Original Brown Swiss, 3; Red Holstein, 3) with an initial age of $4.3 \pm 0.3$ months (mean \pm standard deviation) and an initial BW of $164 \pm 13 \mathrm{~kg}$ were used. Animals were vaccinated as calves with Rispoval RS + PI3 intranasal (Zoetis, Dublin Ireland) prior to entering the feeding experiment but were not dewormed. Experimental groups were created by balancing for initial BW to achieve a comparable average BW among groups. Despite the differing quantities, the variation in the sires $(n=15)$ and the five dam breeds was accounted for to avoid creating treatment groups of animals sired by only one bull or born to only one breed. The experimental groups were then randomly allocated to one of the five experimental diets $(n=6)$.

Bulls were housed in three pens, of ten bulls each, in a free-stall barn with freely accessible, designated areas for the animals to feed, run (with access to an outside area) and lie down. Straw was used as bedding, with fresh straw added three times per week. Two animals of each dietary treatment were represented in each pen. Each animal had exclusive access to its own feeding trough by electronically operated gates and transponder collars (Waagen Doehrn, Wesel, Germany).

All animals received a diet similarly composed of grass silage, maize silage, and concentrate in a ratio of 0.5:0.3:0.2 on DM basis. Two different batches of wilted grass silage were fed, the first from experimental onset until experimental week 26 , and the second from experimental week 27 until the end of the experiment. Both grass silages were obtained from a ryegrass-clover ley (predominantly ryegrass) and harvested at the beginning of ear emergence of the ryegrass in two consecutive years. The first batch was harvested as third 
and fourth cut and was stored in a bunker silo. The second batch was harvested as fourth cut and preserved in large round bales. Two different batches of whole plant maize silage were used. Both were harvested at half milkline stage and stored in bunker silos that were changed in week 11 . No silage additives were used.

The grass and maize silage mixture was freshly prepared every second day. It was offered daily in the morning at ad libitum access. The forage was supplemented with $12 \mathrm{~g} / \mathrm{kg}$ DM of a mineral-vitamin mixture providing, per $\mathrm{kg}$, calcium, $138 \mathrm{~g}$, phosphorus, $46 \mathrm{~g}$, magnesium, $36 \mathrm{~g}$, sodium, $167 \mathrm{~g}$, zinc, $5 \mathrm{~g}$, manganese, $3 \mathrm{~g}$, copper, $1 \mathrm{~g}$, vitamin $\mathrm{A}$, $625,000 \mathrm{IE}$, vitamin $\mathrm{D}_{3}, 62,500 \mathrm{IE}$, vitamin $\mathrm{E}, 1 \mathrm{mg}$, and Saccharomyces cerevisiae (NCYC Sc 47), 333 colony forming units. Additionally, animals had free access to a NaCl-containing licking block. The vitamin-mineral mix was added directly to the forage mixture instead of the experimental concentrates to ensure appropriate allocation of the minerals and vitamins to animals from the beginning of the experiment. At this time point, it was not known whether the palatability of the concentrates and consequently mineral intakes would be impaired. The concentrates were top-dressed by hand twice daily, or three times if the animals were offered $>2 \mathrm{~kg}$ concentrate/day.

One week prior to the start of the experiment, animals were gradually adapted to the experimental diets. From the second experimental week onwards, individual feed intake was recorded throughout the experimental period on two consecutive days of each week by weighing the amount of forage provided and the leftovers after $24 \mathrm{~h}$. In order to maintain the designated silage:concentrate ratio of 0.8:0.2 for each animal throughout the fattening period, individual concentrate allocation was adjusted to measured ad libitum silage intake every 2 weeks.

The BW was measured every second week using a cattle scale (Ixonix FX 15, Texas Trading $\mathrm{GmbH}$, Windach, Germany). Bulls were weighed in the afternoon and were not fasted before weighing.

\subsection{Slaughter, Carcass Quality, and Sampling}

The target live weight for slaughter was set at $520 \mathrm{~kg}$ following the common practice for Terra-Swiss labelled beef. Before slaughter, the animals were fasted overnight for about $12 \mathrm{~h}$ and transported within $45 \mathrm{~min}$ to the University of Zurich's abattoir (Zurich, Switzerland). Slaughters were performed on four different dates within a 62-day period. Animals that achieved a BW near the target weight were selected and grouped, resulting in groups of six, ten, eight, and six bulls slaughtered on the four dates, respectively. On two slaughter dates, at least one animal of each feeding group was slaughtered, whereas on the two other slaughter dates bulls from four of the five treatments were slaughtered. At slaughter, the animals' age averaged $12.6 \pm 0.7$ months. Animals were slaughtered every $35 \mathrm{~min}$ in a random order concerning experimental groups. Stunning using a captive bolt gun was followed by exsanguination. Hot carcass weight was recorded within $30 \mathrm{~min}$ after stunning. Dressing percentage was calculated as the percentage of hot carcass weight to BW the afternoon before slaughtering. Carcasses were graded according to the Swiss classification system CH-TAX [29] for conformation ( $\mathrm{C}=$ excellent, $\mathrm{X}=$ poor $)$ and fatness score ( 1 = too lean, 3 = optimal and homogenous fat cover, 5 = excessively fat) by an independent professional. This system is comparable with the EUROP grading scheme.

Samples of the Musculus longissimus thoracis et lumborum (LTL) were excised $3 \mathrm{~h}$ after stunning from the left carcass side between the 10th thoracic and the 5th lumbar vertebra. A slice of $2 \mathrm{~cm}$ was cut from the caudal side and trimmed of residual adipose and connective tissue. After homogenization in a household blender (Moulinette type DP-700, Moulinex, Ecully, France), the meat was vacuum packed and stored at $-20^{\circ} \mathrm{C}$. The remaining sample was cut into two evenly sized pieces, which were stored uncovered at $4{ }^{\circ} \mathrm{C}$ for $24 \mathrm{~h}$. At $24 \mathrm{~h}$ post mortem (p.m.), muscle samples were gently blotted dry with paper towels, weighed, vacuum packed, and aged for 7 (caudal side) or 21 (cranial side) days at $4{ }^{\circ} \mathrm{C}$.

Heart, liver, spleen, kidney, and perirenal fat were immediately removed from the carcasses and their weight was recorded. Samples of subcutaneous fat were obtained 
within 30 min after stunning from the back of the left carcass, homogenized (Moulinette type DP-700, Moulinex, Ecully, France), vacuum packed and stored at $-20^{\circ} \mathrm{C}$.

\subsection{Feed Sampling and Proximate Analysis of the Feeds}

Samples of grass and maize silage were collected 15 and 11 times, respectively, from both batches of silage to account for possible silage variations. Concentrates were sampled three times as each concentrate was derived from a single batch. The protein sources were derived from one batch each and were sampled once, prior to mixing into the concentrates. The feed refusals were sampled and their composition was analyzed occasionally during the experiment. Since no or only minor differences were observed between the proximate composition of the leftovers and the forage mixture provided, the composition of the leftovers was not further considered. The forage samples were dried at $60{ }^{\circ} \mathrm{C}$ for $48 \mathrm{~h}$ prior to milling. Forages and concentrates were ground in a centrifugal mill (ZM 200, Retsch GmbH, Haan, Germany) to pass a 1-mm sieve before analysis.

All individual feed samples were analyzed for their proximate composition with standard methods [30,31]. Dry matter and total ash were determined using a thermos gravimetric device model (TGS 701, Leco Corporation, St. Josephs, MI, USA; AOAC index no. 942.05). Nitrogen $(\mathrm{N})$ was assessed using a $\mathrm{C} / \mathrm{N}$-analyzer (TruMac $\mathrm{CN}$, Leco Corporation; AOAC index no. 968.06). The $\mathrm{CP}$ was calculated as $6.25 \times \mathrm{N}$. Ether extract (EE) was analyzed in a Soxhlet extractor (extraction system B-811, Buechi, Flawil, Switzerland; AOAC index no. 963.15). Ether extract in spirulina and the spirulina-containing concentrate was determined after $\mathrm{HCl}$ hydrolysis (Hydrolysis Unit B-425, Buechi, Flawil, Switzerland). Ash-corrected neutral detergent fiber (NDF; with heat-stable $\alpha$-amylase from Sigma-Aldrich, St. Louis, MO, USA) and acid detergent fiber (ADF) in feed were measured using the Fibertherm FT 12 (Art. 13-0026, Gerhardt GmbH \& Co. KG, Koenigswinter, Germany; VDLUFA methods 6.5.1 and 6.5.2, respectively). Fiber fractions could not be analyzed in spirulina and SP concentrate due to poor reliability and repeatability of results caused by the extremely fine powder form of the spirulina. Acid detergent lignin (ADL; VDLUFA method 6.5.3) was analyzed in forages by incubation with sulphuric acid (72\%) for $3 \mathrm{~h}$ subsequent to ADF analysis. Protein fractions were determined by standardized procedures [32]. Non-protein N (NPN; fraction A) was calculated as the difference between total $\mathrm{CP}$ and true protein precipitated using tungstic acid. The true protein was distinguished by its solubility in borate-phosphate buffer, neutral, and acid detergent solutions into fractions $B_{1}, B_{2}$, and $B_{3}$, respectively. The true protein insoluble in acid detergent is represented in the $\mathrm{C}$-fraction. In spirulina these fractions could not be distinguished for the same reasons as described for fiber analysis. Instead, the true protein content of spirulina was analyzed (VDLUFA method 4.4.1).

Metabolizable energy (ME) contents of the forages, SBM, and faba beans were estimated based on proximate nutrient composition and digestibility coefficients according to Agroscope [33]. The ME content of pumpkin seed cake was estimated based on linseed cake (80-110 g EE/kg DM) due to missing digestibility coefficients for pumpkin seed cake [33]. For spirulina, ME content was estimated as $0.0159 \times$ digestible $\mathrm{CP}(\mathrm{g} / \mathrm{kg} \mathrm{DM})+0.0377 \times$ digestible $\mathrm{EE}(\mathrm{g} / \mathrm{kg} \mathrm{DM})+0.0147 \times$ digestible $\mathrm{N}$-free extract $(\mathrm{g} / \mathrm{kg} \mathrm{DM})$ [28]. The $\mathrm{N}$-free extract $(\mathrm{g} / \mathrm{kg}$ DM) was calculated as DM $(\mathrm{g} / \mathrm{kg}$ wet weight $)-(\mathrm{ash}(\mathrm{g} / \mathrm{kg} \mathrm{DM})+\mathrm{EE}(\mathrm{g} / \mathrm{kg}$ $\mathrm{DM})+\mathrm{CP}(\mathrm{g} / \mathrm{kg} \mathrm{DM}))$. Digestibility coefficients for $\mathrm{CP}, \mathrm{EE}$, and $\mathrm{N}$-free extract were 0.738 , 0.625 , and, 0.67 , respectively [34]. Values for metabolizable protein resulting from RUP and microbial protein synthesized from ruminal available energy (APDE) and from RUP and microbial protein synthesized from ruminal available nitrogen (APDN) [28] of the forages, SBM and faba bean were estimated according to Agroscope [33]. Metabolizable protein contents of pumpkin seed cake and spirulina could not be estimated due to missing data on ruminal protein degradability. 


\subsection{Analysis of Meat Quality and Fat Shelf Life}

The chemical composition of homogenized meat was analyzed as described for the feed samples. For intramuscular fat, hydrolysis by $\mathrm{HCl}$ was performed before extraction as described by Mueller et al. [35]. Temperature and $\mathrm{pH}$ of the excised LTL sample were measured $24 \mathrm{~h} \mathrm{p.m}$. with a $\mathrm{pH}$ meter with integrated temperature sensor (testo 205, Testo Ltd., Alton, Hampshire, UK). After ageing for 7 or 21 days, the meat was blotted dry and reweighed to determine ageing loss. From the aged samples, two 1-cm thick slices were dissected and allowed to bloom (freshly cut side facing up) for $1 \mathrm{~h}$ in the dark at $4{ }^{\circ} \mathrm{C}$. At five points, color was measured using a Chroma Meter (model CR-300 with light source C, $\mathrm{D}_{65}$; Konica Minolta, Tokyo, Japan) in the CIE L* $\mathrm{a}^{*} \mathrm{~b}^{*}$ (lightness, redness, and yellowness, respectively) color space. Another four 2-cm thick slices were obtained. Both pairs were weighed, one pair was placed individually in a two-layer net and hung in a sealed plastic bag for $24 \mathrm{~h}$ at $4{ }^{\circ} \mathrm{C}$ to determine drip loss [36]. To assess cooking loss, the other two slices were vacuum packed and cooked in a water bath at $75{ }^{\circ} \mathrm{C}$ until they reached a core temperature of $72{ }^{\circ} \mathrm{C}$. The latter was controlled with a digital food thermometer (testo 108, Testo Ltd., Alton). The cooked samples were cooled in cold tap water for $10 \mathrm{~min}$, blotted dry and reweighed. Afterwards, seven to ten cylindrical cores with a diameter of $1.27 \mathrm{~cm}$ were cut from the cooked meat samples in parallel to the muscle fibers with a cork borer. Shear force was measured perpendicular to the muscle fibers on the cores by using a Warner-Bratzler shear force blade attached to a texture analyzer (model ProLine table-top machine Z005, Zwick Roell, Ulm, Germany). Average values per animal were calculated for each variable for statistical analysis.

The homogenized subcutaneous fat was melted at $80^{\circ} \mathrm{C}$ for $60 \mathrm{~min}$ and sieved through a kitchen sieve to remove connective tissue before determining the oxidative stability with a Rancimat (model 697, Metrohm, Herisau, Switzerland) at $110^{\circ} \mathrm{C}$ and an airflow of $20 \mathrm{~L} / \mathrm{h}$.

\subsection{Fatty acid Analysis in Feeds and Meat}

Fatty acid profiles of feed samples and homogenized meat samples were analyzed as outlined by Wolf, et al. [37]. Briefly, total lipids were extracted using hexane:isopropanol (HIP) in a ratio of 3:2 (vol/vol) and FA were converted to FA methyl esters (FAME) under cooking conditions using methanolic $\mathrm{NaOH}$ and $\mathrm{BF}_{3}$ [38], followed by gas chromatographic analysis (HP 6890, Agilent Technologies, Inc., Wilmington, PA, USA). Dietary lipids were extracted using an accelerated solvent extractor (ASE 200, Dionex Coporation, Sunnyvale, CA, USA), while muscle lipids were extracted directly by dispersion in HIP (Polytron ${ }^{\circledR}$ model PT 6000, Kinematica AG, Luzern, Switzerland). Prior to adding methylation reagents, C11:0 triglyceride (Fluka Chemie, Buchs, Switzerland) was added as internal standard. Separation of FAME was performed by injecting $1 \mu \mathrm{L}$ of FAME at a split ratio of 1:20 onto a CP7421 column (wall-coated open tubular fused silica $200 \mathrm{~mm} \times 0.25 \mathrm{~mm}$; Varian Inc., Lake Forest, CA, USA). Compounds were carried by hydrogen at a flow rate of $1.7 \mathrm{~mL} / \mathrm{min}$. Detector temperature was $270{ }^{\circ} \mathrm{C}$. The detailed temperature program is described in Wolf, et al. [37]. Peaks were characterized by comparing the retention times to a 37-component FAME standard (Sigma Aldrich, Steinheim, Germany). Peak areas of FAME were quantified using the HP ChemStation ${ }^{\circledR}$ software (version Rev. B.04.03-SP1; Agilent, Palo Alto, CA, USA). Proportions of FA were expressed as percentage of the total area of FAME injected. Following Ulbricht and Southgate [39], the atherogenicity [(C12:0 $+4 \times \mathrm{C} 14: 0+\mathrm{C} 16: 0) /(\Sigma$ MUFA $+\Sigma n-6+\Sigma n-3)]$ and thrombogenicity $[(\mathrm{C} 14: 0+\mathrm{C} 16: 0+$ C18:0) $/(0.5 \times \Sigma$ MUFA $+0.5 \times \Sigma n-6+3 \times \Sigma n-3+(\Sigma n-6 / \Sigma n-3))]$ of the intramuscular fat were calculated (MUFA: monounsaturated FA).

\subsection{Statistical Analysis}

Data were analyzed with Rstudio (version 1.2.5001; Rstudio, Inc., Boston, MA, USA) using the aov function to assess diet effect on animal-performance related variables. Initial BW was included in the model as a covariate for days on experimental feeds and concentrate DM intake (DMI). This variable was not considered in any other performance-related 
variable as it was found to have no effect. A mixed model analysis using the lmer function was applied for carcass, some meat $\left(\mathrm{pH}_{24} \mathrm{~h}\right.$ post mortem, temperature $24 \mathrm{~h}$ post mortem, chemical composition of fresh meat), and fat quality (oxidative stability) data as well as for FA data considering diet as fixed and slaughter day as random effect as not all animals were slaughtered on the same day. Animal was considered as the experimental unit. Post hoc analysis was done by applying the glht function to test for differences between diets. Data of meat ash content was inverted for statistical analysis. The Box Cox transformation was used to calculate the best $\lambda$ to transform data of age at start of the experiment, meat ash content, C14:1, C16:1, C17:1, C18:2 trans-11, cis-15, C18:2 n-6 cis, C18:3 n-6, C18:3 n-3, C20:4 n-6, C20:5 $n-3$, C22:4 $n-6$, C22:5 n-3, C22:6 n-3, sum of polyunsaturated FA (PUFA), sum of $n-3$ FA, sum of $n-6$ FA, and $n-6 / n-3$ FA ratio. For meat quality data obtained after the two different ageing periods, a mixed model for repeated measures with diet, ageing period and their interaction as fixed effects and slaughter day and animal as random effects was used. A post-hoc test was done by calculating contrast using the glht function to estimate the significance of differences among diets within days of ageing and within diets among days of ageing. Shear force data was square transformed prior to analysis. Results of untransformed data are presented as arithmetic means \pm standard error of the mean (SEM). Effects at $p<0.05$ were considered statistically significant. $P$-values of $0.05<p<0.1$ were considered a trend.

\section{Results}

\subsection{Feed Composition, Growth and Slaughter Performance}

The protein sources differed substantially in $\mathrm{CP}$ content (Table 1), which had to be balanced differently by other concentrate ingredients (Table 2). The NP concentrate provided $135 \mathrm{~g} \mathrm{CP} / \mathrm{kg} \mathrm{DM}$, whereas all other concentrates had an average CP content of $226 \pm 5.0 \mathrm{~g} / \mathrm{kg}$ DM. The complete diets containing the different protein sources were widely isonitrogenous and isoenergetic (Table 3). Depending on the combination of grassand maize silage batches used (Table 2), they contained on average $157 \pm 1.1 \mathrm{~g} \mathrm{CP} / \mathrm{kg}$ and $9.7 \pm 0.06 \mathrm{MJ} \mathrm{ME} / \mathrm{kg}$ DM (Table 3). The SB-diet was on average richer in APDE and APDN than the FB-diet. The NP-diet provided on average $9.7 \pm 0.10 \mathrm{MJ} \mathrm{ME} / \mathrm{kg}$ DM and $139 \pm 2.3 \mathrm{~g} \mathrm{CP} / \mathrm{kg}$ DM with an even more pronounced deficiency $(36,32$ and $28 \%$ at 150 , $200,250 \mathrm{~kg} \mathrm{BW}$ ) in the metabolizable protein supply than the positive control diet.

Table 3. Average proximate composition of complete experimental diets containing soybean meal (SB), faba beans (FB), pumpkin seed cake (PS), spirulina (SP), or no additional protein source (NP).

\begin{tabular}{cccccc}
\hline \multirow{2}{*}{ Proximate Contents (g/kg DM) } & \multicolumn{5}{c}{ Complete Diets } \\
\cline { 2 - 6 } & SB & FB & PS & SP & NP \\
\hline Organic matter & 916 & 916 & 915 & 917 & 916 \\
Crude protein & 158 & 160 & 157 & 155 & 139 \\
Ether extract & 30.8 & 31.8 & 35.3 & 35.0 & 32.5 \\
Neutral detergent fiber & 475 & 476 & 474 & n.a. & 474 \\
Acid detergent fiber & 281 & 288 & 279 & 279 & 286 \\
Gross energy (MJ/kg DM) & 18.1 & 18.1 & 18.1 & 18.2 & 18.0 \\
Metabolizable energy (MJ/kg DM) & 9.8 & 9.6 & 9.8 & 9.8 & 9.7 \\
APDE (g/kg DM) & 85 & 76 & - & - & 75 \\
APDN (g/kg DM) & 100 & 96 & - & - & 85 \\
\hline
\end{tabular}

APDE: metabolizable protein derived from ruminal available energy; APDN: metabolizable protein derived from ruminal protein fermentation; n.a.: not analyzed.

The protein sources also differed regarding their proportions of protein fractions (Table 1). While most of the protein of SBM and pumpkin seed cake belonged to the $\mathrm{B}_{2}$-fraction, a high proportion of the $\mathrm{B}_{1}$-fraction was found in the faba beans. Faba bean $\mathrm{CP}$ had the highest proportion of fraction A.

The FA profile of spirulina differed from that of the other protein sources. The major FA found in spirulina were C16:0, C18:3 $n-6$, and C18:2 $n-6$ cis (descending order). In SBM, 
faba beans, and pumpkin seed cake, the predominant FA were C18:2 n-6 cis, C18:1 cis9, and C16:0 (descending order), whereas no or only traces of C18:3 n-6 were detected. Spirulina contained more than double the amount of total saturated FA (SFA) compared to the other protein sources but only small amounts of monounsaturated FA (MUFA). Soybean meal provided the highest proportion of $n-3$ FA and the lowest $n-6 / n-3$ FA ratio, which was greatest in spirulina. However, the major FA found in all concentrates were identical (C18:2 $n-6$ cis, C18:1 cis-9, and C16:0) but present in varying proportions (Table 2).

The average fattening period (days) as well as initial and slaughter BW (Table 4) were similar for all groups. No differences in BW were found among groups during the experimental period (data not shown). Treatment groups showed similar growth performances at any given time point and ADG did not differ among groups $(1.43 \pm 0.018 \mathrm{~kg}$ across all groups). No differences were observed in DMI for total, silage, or concentrate intakes among groups, thus the feed conversion ratios (DMI/kg ADG) were similar. Concentrate provided at each meal was always completely consumed. Slaughter performance was not affected by diet. On average, all bulls had a carcass weight of $279 \pm 2.0 \mathrm{~kg}$ and a dressing percentage of $53.9 \pm 0.22 \%$. Carcasses received similar and favorable conformation scores at fairly low fat cover scores (Table 4). No significant dietary effects were observed for proportionate organ weights or perirenal fat.

Table 4. Feed intake, growth, and slaughter performance of fattening bulls fed a grass/maize-silage based diet complemented with concentrates containing soybean meal (SB), faba beans (FB), pumpkin seed cake (PS), spirulina (SP), or no additional protein source (NP) ( $n=6$ per group).

\begin{tabular}{|c|c|c|c|c|c|c|c|}
\hline Concentrate & SB & FB & PS & SP & NP & SEM & $p$-Value \\
\hline Average fattening period (days) & 245 & 246 & 253 & 253 & 245 & 11.5 & 0.837 \\
\hline Age at start (months) & 4.4 & 4.4 & 4.4 & 4.2 & 4.3 & 0.22 & 0.860 \\
\hline \multicolumn{8}{|l|}{ Body weight $(\mathrm{kg})$} \\
\hline Initial (start of experiment) & 164 & 165 & 161 & 164 & 166 & 8.28 & 0.971 \\
\hline At slaughter & 518 & 522 & 524 & 518 & 510 & 5.82 & 0.428 \\
\hline Average weight gain (kg/day) & 1.45 & 1.46 & 1.44 & 1.40 & 1.41 & 0.047 & 0.771 \\
\hline \multicolumn{8}{|l|}{ DM intake (DMI; kg/day) } \\
\hline Total & 6.79 & 6.85 & 7.02 & 6.96 & 6.98 & 0.217 & 0.845 \\
\hline Silage & 5.43 & 5.50 & 5.60 & 5.56 & 5.58 & 0.178 & 0.872 \\
\hline Concentrate & 1.36 & 1.35 & 1.42 & 1.40 & 1.40 & 0.045 & 0.647 \\
\hline Feed conversion ratio (kg DMI/kg gain) & 4.69 & 4.69 & 4.88 & 4.94 & 4.98 & 0.207 & 0.467 \\
\hline Hot carcass weight $(\mathrm{kg})$ & 278 & 279 & 287 & 278 & 276 & 5.26 & 0.318 \\
\hline Dressing percentage & 53.7 & 53.4 & 54.8 & 53.6 & 54.0 & 0.59 & 0.532 \\
\hline Conformation score 2 & 3.7 & 3.9 & 4.4 & 3.7 & 3.7 & 0.30 & 0.220 \\
\hline Fat cover score ${ }^{3}$ & 2.4 & 1.7 & 2.3 & 1.8 & 2.3 & 0.44 & 0.406 \\
\hline \multicolumn{8}{|l|}{ Organ weights (g/kg carcass weight) } \\
\hline Heart & 6.58 & 6.80 & 6.64 & 7.00 & 7.03 & 0.301 & 0.279 \\
\hline Liver & 21.6 & 22.2 & 21.0 & 20.7 & 20.8 & 0.68 & 0.106 \\
\hline Spleen & 3.77 & 3.52 & 3.26 & 3.86 & 3.44 & 0.292 & 0.078 \\
\hline Kidneys & 3.75 & 3.76 & 3.49 & 3.61 & 3.78 & 0.650 & 0.491 \\
\hline Perirenal fat (g/kg carcass weight) & 14.0 & 13.3 & 15.3 & 17.6 & 12.1 & 3.12 & 0.183 \\
\hline
\end{tabular}

n.s.: not significant; SEM: standard error of the mean. ${ }^{1}$ Data were transformed for statistical analysis but means of nontransformed data are presented in the table. ${ }^{2}$ Defined as $1=$ poor and $5=$ excellent according to $\mathrm{CH}$-TAX classification. ${ }^{3}$ Defined as $1=$ too lean, $3=$ optimum, evenly covered with fat, $5=$ excessively fat according to $\mathrm{CH}-\mathrm{TAX}$ classification.

\subsection{Physicochemical Meat Quality}

At $24 \mathrm{~h}$ p.m., $\mathrm{pH}$ and temperature in excised LTL samples were similar among diets (Table 5). Muscles from all groups had similar contents of moisture, protein, intramuscular fat, and ash. Diet had no effect on the oxidative stability of the subcutaneous fat. Ageing loss increased with ageing time $(p=0.003)$ across all groups but was only prevalent $(p=0.005)$ in SP. Drip loss remained unaffected by diet and ageing period, while cooking loss tended $(p=0.075)$ to differ between diets. Meat color variables did not differ among diets but varied (all $p<0.001$ ) with ageing period. Overall, lightness increased with time 
but within experimental groups, this effect reached significance only in $\mathrm{SB}(p=0.009)$ and PS $(p=0.005)$. After 21 days of ageing, the beef from SB, FB, PS, and NP was more red than after 7 days of ageing $(p=0.018 ; p=0.026 ; p<0.001 ; p=0.005$, respectively). Yellowness was more intense after 21 days compared to 7 days of ageing in SB $(p=0.002)$, PS $(p=0.007)$, and NP $(p=0.002)$, whereas in FB it tended to vary $(p=0.088)$. Shear force was similar between groups but values were lower $(p<0.001)$ after 21 compared to 7 days of ageing. In variables where ageing was investigated, no significant dietary interactions occurred.

Table 5. Physicochemical quality of the longissimus thoracis et lumborum aged for 7 or 21 days from fattening bulls fed a grass/maize-silage based diet complemented with concentrates containing various protein sources or no additional protein source ( $n=6$ per group).

\begin{tabular}{|c|c|c|c|c|c|c|c|c|c|c|c|c|c|c|}
\hline Concentrate (C) & \multicolumn{2}{|c|}{ SB } & \multicolumn{2}{|c|}{ FB } & \multicolumn{2}{|c|}{ PS } & \multicolumn{2}{|c|}{ SP } & \multicolumn{2}{|c|}{ NP } & SEM & \multicolumn{3}{|c|}{$p$-Values } \\
\hline $\mathrm{pH}_{24} \mathrm{~h}$ postmortem & \multicolumn{2}{|c|}{5.63} & \multicolumn{2}{|c|}{5.67} & \multicolumn{2}{|c|}{5.81} & \multicolumn{2}{|c|}{5.75} & \multicolumn{2}{|c|}{5.64} & 0.109 & \multicolumn{3}{|c|}{0.515} \\
\hline \multicolumn{15}{|l|}{$\begin{array}{l}\text { Chemical } \\
\text { composition } \\
(\mathrm{g} / \mathrm{kg})\end{array}$} \\
\hline Moisture & \multicolumn{2}{|c|}{739} & \multicolumn{2}{|c|}{754} & \multicolumn{2}{|c|}{748} & \multicolumn{2}{|c|}{751} & \multicolumn{2}{|c|}{750} & 4.9 & \multicolumn{3}{|c|}{0.127} \\
\hline Protein & \multicolumn{2}{|c|}{232} & \multicolumn{2}{|c|}{223} & \multirow{2}{*}{\multicolumn{2}{|c|}{222}} & \multicolumn{2}{|c|}{225} & \multicolumn{2}{|c|}{228} & 3.7 & \multicolumn{3}{|c|}{0.141} \\
\hline Fat (Ether extract) & \multirow{2}{*}{\multicolumn{2}{|c|}{$\begin{array}{l}8.91 \\
12.3\end{array}$}} & \multirow{2}{*}{\multicolumn{2}{|c|}{$\begin{array}{l}8.27 \\
13.2\end{array}$}} & & & & & & & 2.047 & & 0.995 & \\
\hline Ash $^{1}$ & & & & & & & & & & & 0.93 & & 0.076 & \\
\hline $\begin{array}{c}\text { Oxidative } \\
\text { stability (h) }\end{array}$ & & & & & & & & & & & 1.28 & & 0.641 & \\
\hline $\begin{array}{l}\text { Ageing Period in } \\
\text { Days (A) }\end{array}$ & 7 & 21 & 7 & 21 & 7 & 21 & 7 & 21 & 7 & 21 & & $\mathrm{C}$ & $\mathbf{A}$ & $\mathbf{C} \times \mathbf{A}$ \\
\hline $\begin{array}{l}\text { Water holding } \\
\text { capacity }(\%)\end{array}$ & & & & & & & & & & & & & & \\
\hline Aging loss & 1.33 & 1.61 & 1.26 & 1.40 & 1.29 & $1.35^{2}$ & $1.37^{\mathrm{a}}$ & $1.95^{\mathrm{b}}$ & 1.41 & $1.72^{2}$ & 0.258 & 0.510 & 0.003 & 0.377 \\
\hline Drip loss & 1.14 & 1.04 & 0.97 & 0.96 & 0.79 & 0.94 & 1.02 & 1.08 & 0.93 & 0.890 & 0.181 & 0.625 & 0.850 & 0.798 \\
\hline $\begin{array}{l}\text { Cooking loss } \\
\text { Color }\end{array}$ & 23.7 & 24.8 & 24.0 & 23.4 & 22.9 & $19.2^{2}$ & 25.7 & 25.9 & 24.9 & 22.0 & 2.58 & 0.075 & 0.244 & 0.495 \\
\hline $\mathrm{L}^{*}$ (lightness) & $39.8^{a}$ & $42.0^{b}$ & 40.7 & 41.9 & $38.0^{\mathrm{a}}$ & $40.3^{b}$ & 40.5 & 40.8 & 40.1 & 41.6 & 1.26 & 0.298 & $<0.001$ & 0.266 \\
\hline $\mathrm{a}^{*}$ (redness) & $15.6^{\mathrm{a}}$ & $16.7^{b}$ & $15.9^{a}$ & $16.9^{b}$ & $14.2^{\mathrm{a}}$ & $16.2^{b}$ & 15.3 & 15.8 & $15.3^{a}$ & $16.6^{\mathrm{b}}$ & 0.97 & 0.667 & $<0.001$ & 0.092 \\
\hline $\mathrm{b}^{*}$ (yellowness) & $11.6^{\mathrm{a}}$ & $13.6^{b}$ & 12.2 & 13.6 & $10.7^{\mathrm{a}}$ & $12.5^{\mathrm{b}}$ & 12.0 & 12.6 & $11.3^{\mathrm{a}}$ & $13.4^{\mathrm{b}}$ & 0.7 & 0.418 & $<0.001$ & 0.356 \\
\hline Shear force $(\mathrm{N})^{1}$ & $100.9^{b}$ & $77.4^{\mathrm{a}}$ & $89.3^{b}$ & $64.7^{\mathrm{a}}$ & $97.6^{b}$ & $69.8^{\text {a } 2}$ & $98.0^{\mathrm{b}}$ & $70.7^{a}$ & $100.4^{\mathrm{b}}$ & $72.7^{\mathrm{a}}$ & 7.68 & 0.505 & $<0.001$ & 0.805 \\
\hline
\end{tabular}

FB: faba beans; NP: no additional protein source; PS: pumpkin seed cake; SB: soybean meal; SEM: standard error of the mean; SP: spirulina.

${ }^{1}$ Data were transformed for statistical analysis but means of nontransformed data are presented in the table. ${ }^{2}$ Means calculated with $n=5$.

$\mathrm{a}, \mathrm{b}$ Means carrying different superscripts within variable and feeding group are different at $p<0.05$.

\subsection{Fatty Acid Profile of Intramuscular Fat}

Proportions of the major FA were comparable for all groups (Table 6), with an average of $32.6 \pm 0.60,23.6 \pm 0.29$, and $15.3 \pm 0.31 \mathrm{~g} / 100 \mathrm{~g}$ FA for C18:1 cis-9, C16:0, and C18:0, respectively. Dietary effects were found for C16:0 iso $(p=0.031)$ and C18:1 cis-12 $(p=0.015)$. The SB meat had a higher $(p=0.026)$ proportion of C16:0 iso compared to PS meat. The C18:1 cis-12 proportion was higher for PS than for SB and SP meat ( $p=0.049$ and $p=0.047$, respectively). Proportions of C18:1 trans-11 tended to differ among groups ( $p=0.058)$. Diet had no significant effects on any other FA. However, when numerically comparing proportions of $\mathrm{C} 18: 3 n-3, \mathrm{C} 20: 4 n-6, \mathrm{C} 20: 5 n-3$, and C22:5 $n-3$, they were $45 \%, 27 \%, 36 \%$, and 20\% higher in NP than SB, respectively. Classes of SFA, MUFA, and PUFA as well as $n-6$ and $n-3$ FA remained unaffected. A significant difference among groups was found for the $n-6 / n-3$ FA ratio, which was lower for FB compared to PS $(p<0.001)$ and NP $(p=0.008)$, and for SP compared to PS $(p=0.008)$. Neither the atherogenicity nor thrombogenicity index was affected by the diet. 
Table 6. Fatty acid (FA) profile of the longissimus thoracis et lumborum of fattening bulls fed a grass/maize-silage based diet complemented with concentrates containing soybean meal (SB), faba beans (FB), pumpkin seed cake (PS), spirulina (SP), or no additional protein source (NP), ( $n=6$ per group).

\begin{tabular}{|c|c|c|c|c|c|c|c|}
\hline FA (g/100 g Total FA) ${ }^{1}$ & SB & FB & PS & SP & NP & SEM & $p$-Value \\
\hline C14:0 & 2.10 & 1.70 & 1.73 & 1.88 & 1.84 & 0.217 & 0.866 \\
\hline $\mathrm{C} 14: 1^{2}$ & 0.48 & 0.39 & 0.38 & 0.36 & 0.37 & 0.151 & 0.871 \\
\hline C15:0 & 0.44 & 0.43 & 0.43 & 0.43 & 0.44 & 0.030 & 0.984 \\
\hline $\mathrm{C} 15: 0$ iso & 0.21 & 0.20 & 0.19 & 0.20 & 0.21 & 0.015 & 0.641 \\
\hline C16:0 & 24.1 & 23.4 & 23.7 & 23.9 & 23.1 & 0.94 & 0.838 \\
\hline $\mathrm{C} 16: 0$ iso & $0.21^{b}$ & $0.20^{a b}$ & $0.17^{\mathrm{a}}$ & $0.20^{\mathrm{ab}}$ & $0.18^{a b}$ & 0.009 & 0.031 \\
\hline $\mathrm{C} 16: 1^{2}$ & 3.30 & 2.93 & 2.79 & 3.04 & 2.83 & 0.526 & 0.728 \\
\hline $\mathrm{C} 16: 1 \mathrm{x}$ & 0.51 & 0.48 & 0.43 & 0.46 & 0.47 & 0.043 & 0.420 \\
\hline $\mathrm{C} 17: 0$ & 0.79 & 0.82 & 0.75 & 0.75 & 0.79 & 0.061 & 0.829 \\
\hline $\mathrm{C} 17: 1^{2}$ & 0.13 & 0.12 & 0.16 & 0.23 & 0.15 & 0.070 & 0.688 \\
\hline $\mathrm{C} 17: 0$ anteiso & 0.21 & 0.24 & 0.29 & 0.15 & 0.15 & 0.086 & 0.384 \\
\hline C18:0 & 15.5 & 15.2 & 15.0 & 15.2 & 15.7 & 1.02 & 0.677 \\
\hline C18:1 trans -9 & 0.21 & 0.22 & 0.21 & 0.19 & 0.19 & 0.018 & 0.371 \\
\hline C18:1 trans-11 & 1.04 & 0.84 & 0.91 & 0.92 & 1.11 & 0.092 & 0.058 \\
\hline C18:1 trans-12 & 0.21 & 0.20 & 0.22 & 0.20 & 0.22 & 0.017 & 0.636 \\
\hline C18:1 cis-9 & 33.3 & 33.8 & 32.7 & 32.9 & 30.0 & 1.94 & 0.319 \\
\hline C18:1 cis-11 & 1.42 & 1.46 & 1.45 & 1.51 & 1.48 & 0.101 & 0.924 \\
\hline C18:1 cis-12 & $0.21^{\mathrm{a}}$ & $0.22^{a b}$ & $0.29^{b}$ & $0.21^{\mathrm{a}}$ & $0.28^{a b}$ & 0.026 & 0.015 \\
\hline C18:1 cis-13 & 0.20 & 0.21 & 0.20 & 0.19 & 0.18 & 0.035 & 0.870 \\
\hline C18:2 trans- 11, cis- $15^{2}$ & 0.20 & 0.18 & 0.17 & 0.18 & 0.20 & 0.024 & 0.309 \\
\hline C18:2 n-6 cis 2 & 5.93 & 6.20 & 7.38 & 6.43 & 8.70 & 1.613 & 0.319 \\
\hline$C 18: 3 n-6^{2}$ & 0.11 & 0.20 & 0.10 & 0.15 & 0.08 & 0.085 & 0.521 \\
\hline $\mathrm{C} 18: 3 n-3^{2}$ & 1.91 & 2.16 & 2.11 & 2.26 & 2.78 & 0.527 & 0.491 \\
\hline C18:2 cis- 9, trans -11 & 0.32 & 0.27 & 0.29 & 0.27 & 0.33 & 0.028 & 0.310 \\
\hline C20:3n-6 & 0.44 & 0.50 & 0.58 & 0.56 & 0.53 & 0.096 & 0.741 \\
\hline$C 20: 4 n-6^{2}$ & 2.10 & 2.29 & 2.52 & 2.41 & 2.66 & 0.411 & 0.844 \\
\hline$C 20: 5 n-3^{2}$ & 0.77 & 1.03 & 0.96 & 1.00 & 1.05 & 0.200 & 0.775 \\
\hline $\mathrm{C} 22: 4 n-6$ & 0.19 & 0.19 & 0.21 & 0.20 & 0.21 & 0.027 & 0.884 \\
\hline$C 22: 5 n-3^{2}$ & 1.31 & 1.49 & 1.55 & 1.47 & 1.57 & 0.232 & 0.900 \\
\hline $\mathrm{C} 22: 6 n-3^{2}$ & 0.20 & 0.25 & 0.22 & 0.21 & 0.21 & 0.068 & 0940 \\
\hline$\sum$ Saturated FA & 44.4 & 43.0 & 43.1 & 43.5 & 43.1 & 1.35 & 0.846 \\
\hline$\sum$ Monounsaturated FA & 41.8 & 41.7 & 40.5 & 41.0 & 38.2 & 2.24 & 0.496 \\
\hline$\sum$ Polyunsaturated FA ${ }^{2}$ & 13.8 & 15.2 & 16.4 & 15.5 & 18.7 & 3.08 & 0.630 \\
\hline$\sum n-3 F^{2}$ & 4.36 & 5.13 & 5.02 & 5.13 & 5.84 & 0.973 & 0.765 \\
\hline$\sum n-6 \mathrm{FA}^{2}$ & 8.8 & 9.5 & 10.8 & 9.8 & 12.3 & 2.14 & 0.519 \\
\hline$n-6 / n-3$ FA $^{2}$ & $2.02 \mathrm{abc}$ & $1.85^{\mathrm{a}}$ & $2.15^{c}$ & $1.91^{\mathrm{ab}}$ & $2.11^{b c}$ & 0.077 & 0.002 \\
\hline Atherogenicity index & 0.59 & 0.54 & 0.55 & 0.56 & 0.54 & 0.088 & 0.762 \\
\hline Thrombogenicity index & 1.03 & 0.96 & 0.96 & 0.97 & 0.93 & 0.080 & 0.812 \\
\hline
\end{tabular}

SEM: standard error of the means. ${ }^{1}$ Only fatty acids making up $>0.2 \mathrm{~g} / 100 \mathrm{~g}$ are displayed, all others were considered as traces. ${ }^{2}$ Data were transformed for statistical analysis but means of nontransformed data are presented in the table. ${ }^{a, b, c}$ Means carrying different superscripts within variable are different at $p<0.05$.

\section{Discussion}

\subsection{Characteristics of Protein Sources Tested}

Tested protein sources differed in $\mathrm{CP}$ content; however, values were within the ranges previously reported in the literature for each protein source $[11,17,20,40,41]$. The numerical variations in the $\mathrm{CP}$ fractions, however, reflect likely differences in protein solubility and thus indicate differences in RPD [32]. The high proportion of the $B_{2}$-fraction of SBM refers to a low RPD, whereas the numerically high proportions of the $A$ and $B_{1}$-fractions in faba beans indicate a rather high RPD, which is consistent with former reports [41,42]. The comparably high proportion of the $\mathrm{B}_{2}$-fraction in the pumpkin seed cake used in the present study indicates a moderate RPD, ranging between that of faba beans and SBM. However, to provide a better estimation of the alternative protein sources' nutritional value 
for ruminants, particularly for pumpkin seed cake and spirulina, further investigations regarding the RPD using different batches of these protein sources are required to perform statistical analysis and validate the present results.

No meaningful fractionation was possible for spirulina due to its powdery form. Costa, et al. [43] reported a higher in vitro protein degradability for spirulina than for SBM, whereas Wild, et al. [44] found a limited in vitro protein fermentation, indicating a high proportion of RUP in spirulina but a low intestinal digestibility. This requires further clarification. In general, differences in the RPD between different protein sources had no effect on animal performance, carcass, and meat quality traits in the present study. This may differ in maize-silage based diets, which is generally limited in metabolizable protein.

\subsection{Growth and Slaughter Performance}

The absence of effects on intake, growth, and carcass quality, when replacing SBM with faba beans, support the results of previous studies with Simmental bulls fed a maize-silage based diet [16] and Marchigiana bulls fed a diet with $>550 \mathrm{~g}$ concentrate $/ \mathrm{kg}$ total diet DM [45]. Cutrignelli, et al. [45] observed a lower BW at an earlier fattening period for animals fed faba beans instead of SBM, possibly due to limited RUP supply. However, in the present study, no differences were found in growth performance at any given time point. Despite these converse results, faba beans seem to be an appropriate replacement for SBM in the diets of fattening bulls. Puhakka, et al. [46] observed a reduction in silage and total DMI when including faba beans in the diets of dairy cattle resulting in a decreased milk and milk protein yield. This contrasted with the present intake findings. High palatability is a prerequisite for an alternative protein source. Contrasting findings suggest that investigating the palatability of faba beans compared to SBM in a larger animal study may be of interest.

Similar to the present study, the suitability of pumpkin seed cake as a replacement for SBM was confirmed by Antunović, et al. [18] in lambs (similar carcass quality with partial SBM replacement) and by Klir, et al. [19] in dairy goats when SBM was completely substituted (no change in milk yield). These results coincide with the present outcomes and suggest that pumpkin seed cake has a high palatability and indeed presents an interesting alternative to SBM in the nutrition of different ruminant species.

In contrast to the present findings, the inclusion of spirulina in dairy cow diets reduced DMI [47] or concentrate intake when mixed with spirulina $[26,48]$. This discrepancy in results indicates that the addition of pure spirulina powder (mixed with water) to the total mixed ration or concentrate proportion, in the mentioned studies, likely decreased the palatability of the respective feed. In the present study, spirulina was pre-mixed with all concentrate ingredients, this avoided potential palatability problems. Likewise, Manzocchi, et al. [27] did not observe a reduction in DMI when mixing spirulina with molasses into a hay-based diet fed to dairy cows. Importantly, experimental concentrates applied in the present study were always completely consumed by the animals, indicating a high palatability of these concentrates independent of protein source and presentation (pelleted vs. meal).

The similar animal performance, even when omitting additional protein sources, likely resulted from the comparably higher dietary proportion of grass silage than typically included in conventional diets for fattening bulls in Switzerland that consist primarily of maize silage [1]. Additionally, the CP content (about $175 \mathrm{~g} / \mathrm{kg} \mathrm{DM}$ ) of the grass silage used in the present experiment was fairly high compared to the usual range of 100 to $160 \mathrm{~g} / \mathrm{kg}$ DM [14]. Studies in growing cattle fed ad libitum high-quality grass silage and grain-based concentrates showed that an additional protein supply had no or a limited overall effect on the growth performance and carcass quality $[6-8,10]$, indicating a sustained microbial protein synthesis.

In contrast, decreasing the amount of concentrate in grass-silage based diets may limit microbial protein synthesis due to limited ruminal available energy, thus increasing the likelihood of a greater response to RUP supply $[8,10]$. This may be particularly relevant 
during the early growth period in which the requirements for metabolizable protein, in relation to metabolizable energy, are higher [28]. However, the postulated metabolizable protein requirements were not sufficiently met by the SB-diet in the present study, particularly in the early growth period. The deficiency in metabolizable protein in relation to the postulated requirements was most pronounced in the NP-diet. Therefore, it was even more surprising that the omission of a protein supplement did not impair growth performance. Thus, it can be assumed that the supply of metabolizable protein was already sufficiently met by the forage as well as the grain proportion of the concentrate or that metabolizable energy was the more limiting factor. The latter is unlikely as the average ADG of $1.43 \mathrm{~kg}$ in the present study was almost as high as that reported by Staerfl, et al. [49] for Limousin bulls fattened on a common intensive maize silage/concentrate beef cattle diet. Consequently, the present results indicate that the metabolizable protein requirements for growing crossbred Limousin bulls are likely overestimated. This requires further investigation, also regarding other commonly used beef cattle breeds.

Unexpectedly, all groups showed a higher growth performance than initially predicted. This inconsistency could be explained by a higher muscle (protein) retention potential than anticipated in the feeding recommendations, which provide an average recommendation for various breeds.

Despite the higher growth performance observed in the present study, the target fat cover score of 3 was not met by any of the experimental diets, while dressing percentage and carcass conformation were satisfactory in all groups and comparable to results of Staerfl et al. [49]. Carcasses graded with lower fat cover scores are usually less desirable for retail which may significantly reduce the profit margin when farmers are paid for carcass quality traits. Extending the fattening period may have resulted in better fat cover scores but would have increased final BW and thus carcass weight. Heavier carcasses do not comply to the desired standards of the Swiss beef market and likewise lead to a reduction in the profit margin. Additionally, a longer fattening period may have decreased meat tenderness due to increased age at slaughter [50]. Improving these aspects potentially outweighs the lower fat cover.

Subcutaneous fat deposition mainly depends on energy supply, which is crucial during the late fattening period [51]. As the diet composition was not modified over the course of the present experiment, the lower proportions of concentrate and maize silage compared to conventional beef cattle diets were clearly limited in energy supply during late fattening. Further investigations are required to assess the optimal time point to adjust the energy supply for an optimal fat cover score while maintaining the highest possible amount of grass silage in the diet.

\subsection{Meat Quality}

The physicochemical meat quality was not affected by the diets, including that without protein supplementation. In contrast, Cutrignelli, et al. [52] found a reduced water holding capacity in meat of faba-bean fed Marchigiana bulls and Calabrò et al. [15] observed a slight reduction in intramuscular fat content in meat of buffalo bulls fed faba beans instead of SBM. The partial substitution of SBM by pumpkin seed cake fed to fattening lambs did not affect meat color [18], which supports the present results obtained with a complete replacement of SBM by pumpkin seed cake. It also seems that omitting protein supplementation (here rapeseed meal) in grass-silage and barley-based diets is without consequence for meat composition, water holding capacity, meat color, and shear force of beef cattle [8] which is comparable to the present study.

The prolongation of ageing time from 1 to 3 weeks, following common Swiss practice, significantly affected some of the meat quality traits. Ageing loss was increased by $21 \%$, especially in SP but this from a generally low level. Numerical values are consistent with findings reported by Li et al. [53] for beef aged in vacuum for 8 or 19 days. Lightness, redness, and yellowness increased with prolonged ageing within SB and PS, while in NP, lightness was not affected and in FB, only redness was affected. This partly disagrees 
with Li, et al. [53], who only found an ageing time effect on lightness, but not on red- or yellowness in vacuum aged beef. On the other hand, color changes due to ageing have been previously reported for vacuum aged beef by Boakye and Mittal [54]. However, the meat color remained unaffected by ageing in SP, which may be attributed to the high content of antioxidant carotenoids in spirulina possibly transferred to the muscle tissue [21,55]. Prolonging ageing successfully promoted tenderization, as exhibited from the lower shear force and reported repeatedly by others $[56,57]$.

\subsection{Fatty Acid Profile of the Intramuscular Fat}

Few and minor changes were found in the FA profile (namely in C16:0 iso, C18:1 cis-12, and, in tendency, in C18:1 trans-11) of the intramuscular fat in response to the different diets. Although the concentrates SB, PS, and NP provided numerically higher proportions of PUFA than FB and SP, the PUFA proportion in the LTL remained unaffected. The overall moderate fat content in the concentrates as well as biohydrogenation of unsaturated FA in the rumen may have contributed to this finding. Compared to meat of bulls fed a conventional diet based on maize and concentrate $[15,58,59]$, generally higher proportions of PUFA and $n-3$ FA and a favorably lower $n-6 / n-3$ FA ratio (1.9 to 2.2) in meat lipids were observed across all groups in the present study. This can be explained by the higher amount of grass silage fed in the present study, which provided higher dietary proportions of PUFA, particularly $n-3$ FA, to the animals and consequently improved the $n-6 / n-3$ FA ratio compared to maize-silage based diets $[49,58]$. From the human nutrition perspective, a high intake of PUFA with an $n-6 / n-3$ FA ratio of $\leq 4: 1$, is considered beneficial for maintaining health and reducing the risk of cardiovascular diseases [60]. The ratio of $n-6 / n-3$ FA was favorably reduced by the FB compared to the PS diet, even though this difference was slight. Considering the low-fat content of the beef, the improved $n-6 / n-$ 3 FA ratio would likely have a limited relevance regarding the meat nutritional value for human consumption.

Surprisingly, feeding of spirulina with its particularly deviating FA profile had no clear effect on the FA profile of intramuscular fat, including C18:3n-6, which was highly prevalent in spirulina. Kashani et al. [61] supplemented dual-purpose lambs with spirulina and reported slightly lower C18:3n-6 proportions in their microalga material compared to that used in the present study (17.2 vs. $26.7 \mathrm{~g} / 100 \mathrm{~g}$ FA). For the lambs' Longissimus dorsi muscle, no proportion of C18:3n-6 was reported in the presentation of the FA profile, leading to the assumption that this characteristic FA was not detected and/or there were no differences to report. In contrast, when spirulina was fed to dairy cows [27], the milk fat showed higher proportions of C18:3n-6, even though only to a small extent. The differences in the transfer of C18:3 n-6 to milk [27] and muscle tissue (present study) cannot be explained with certainty. It is probable that differences in ruminal biohydrogenation and generally different FA transport efficiencies, to milk and meat, played a role in this finding.

\section{Conclusions}

Based on the present findings, SBM can be replaced by any of the tested protein sources on an isonitrogenous basis in diets comprising 50\% grass silage, $30 \%$ maize silage, and $20 \%$ concentrate without impairing performance, thus confirming hypothesis (i). Nevertheless, this may differ in typical maize-silage based fattening diets with particularly limited metabolizable protein supply. Additional studies are required to evaluate the potential of these protein sources to replace SBM in such diets. Notably, omitting additional dietary protein resulted in a comparable fattening and slaughter performance, disproving hypothesis (ii). It can be concluded that the combination of grass and maize silage and a wheat-based concentrate provided enough metabolizable protein for Limousin crossbred bulls with an ADG of about $1.43 \mathrm{~kg}$ or that the bulls' growth potential was higher but compromised due to other factors, for instance dietary energy. As none of the diets affected carcass and meat quality, hypothesis (iii) was confirmed. Hypothesis (iv) was disproved as no difference in meat FA profiles were observed. 
In summary, the high dietary proportion of grass silage improved the meat FA profile compared to values reported for conventional fattening diets, while maintaining reasonable animal performance and carcass and meat quality, without additional metabolizable protein-concentrate supplementation. This is good news from an environmental perspective, as omitting additional protein likely lowers urinary and fecal nitrogen excretion, and thus, limits ammonia emission. Moreover, if a grass-silage based diet does not require additional protein supplements, the independence from imported SBM is enhanced and high costs to produce alternative protein sources, particularly spirulina, are avoided.

Author Contributions: Conceptualization, M.K., B.R., A.S., and K.G.; methodology, M.K. and K.G.; formal analysis, M.K. and K.G.; investigation, M.K.; resources, L.E.; writing—original draft preparation, M.K. and K.G.; writing—review and editing, M.K., B.R., A.S., L.E., I.M., and K.G.; supervision, K.G. All authors have read and agreed to the published version of the manuscript.

Funding: We thank the Federation of Migros Cooperatives, Micarna SA, ETH Zurich Foundation and World Food System Center of ETH Zurich for the financial support of this study.

Institutional Review Board Statement: The animal experiment was approved by the Cantonal Veterinary Office of Zurich, Switzerland (license no. ZH129/18).

Data Availability Statement: The datasets used and analysed during the current study are available from the corresponding author on reasonable request.

Acknowledgments: We thank the $\mathrm{CH}-\mathrm{Beef}+$ project team for lively discussions and their knowledge input when planning the experiment. We are grateful to the staff of AgroVet-Strickhof and ETH Zurich for their assistance and support during the animal experiment and in the lab, especially $\mathrm{P}$. Bucher, I. Gangnat, M. Heuel, C. Kunz, R. Lugarà, M. Mergani, H. Renfer, and his team, T. Stiefel and M. Terranova. We thank A. Birkinshaw for English language editing. The support by P. Müller and D. Heller of the University of Zürich abattoir is greatly acknowledged.

Conflicts of Interest: The authors declare no conflict of interest.

\section{References}

1. Janett, R.M.; Wyss, M.; Favre, J.; Scheurer, A.; Reidy, B. Teil I: Eckpunkte einer Umweltfreundlichen und Effizienten Erzeugung von Hochwertigem Rindfleisch unter Schweizer Produktionsbedingungen; Project report; Bern University of Applied Sciences, School of Agricultural, Forest and Food Sciences HAFL: Zollikofen, Switzerland, 2021.

2. Leguizamón, A. Modifying Argentina: GM soy and socio-environmental change. Geoforum 2014, 53, 149-160. [CrossRef]

3. Prudêncio da Silva, V.; van der Werf, H.M.G.; Spies, A.; Soares, S.R. Variability in environmental impacts of Brazilian soybean according to crop production and transport scenarios. J. Environ. Manag. 2010, 91, 1831-1839. [CrossRef]

4. Juniper, D.T.; Browne, E.M.; Fisher, A.V.; Bryant, M.J.; Nute, G.R.; Beever, D.E. Intake, growth and meat quality of steers given diets based on varying proportions of maize silage and grass silage. Anim. Sci. 2005, 81, 159-170. [CrossRef]

5. Keady, T.W.J. Ensiled maize and whole crop wheat forages for beef and dairy cattle: Effects on animal performance. In Silage Production and Utilisation, Proceedings of the XIVth International Silage Conference, a Satellite Workshop of the XXth International Grassland Congress, Belfast, Northern Ireland, July 2005; Park, R.S., Stronge, M.D., Eds.; Wageningen Academic Publishers: Wageningen, The Netherlands, 2005; pp. 65-82. [CrossRef]

6. Huuskonen, A. Effects of barley grain compared to commercial concentrate or rapeseed meal supplementation on performance of growing dairy bulls offered grass silage-based diet. Agr. Food Sci. 2011, 20, 191-205. [CrossRef]

7. Huuskonen, A.; Khalili, H.; Joki-Tokola, E. Effects of three different concentrate proportions and rapeseed meal supplement to grass silage on animal performance of dairy-breed bulls with TMR feeding. Livest. Sci. 2007, 110, 154-165. [CrossRef]

8. Pesonen, M.; Honkavaara, M.; Kamarainen, H.; Tolonen, T.; Jaakkola, M.; Virtanen, V.; Huuskonen, A. Effects of concentrate level and rapeseed meal supplementation on performance, carcass characteristics, meat quality and valuable cuts of Hereford and Charolais bulls offered grass silage-barley-based rations. Agr. Food Sci. 2013, 22, 151-167. [CrossRef]

9. Huuskonen, A.; Huhtanen, P. The development of a model to predict BW gain of growing cattle fed grass silage-based diets. Animal 2015, 9, 1329-1340. [CrossRef] [PubMed]

10. Huuskonen, A.; Huhtanen, P.; Joki-Tokola, E. Evaluation of protein supplementation for growing cattle fed grass silage-based diets: A meta-analysis. Animal 2014, 8, 1653-1662. [CrossRef] [PubMed]

11. Halmemies-Beauchet-Filleau, A.; Rinne, M.; Lamminen, M.; Mapato, C.; Ampapon, T.; Wanapat, M.; Vanhatalo, A. Review: Alternative and novel feeds for ruminants: Nutritive value, product quality and environmental aspects. Animal 2018, 12, s295-s309. [CrossRef] [PubMed]

12. Singh, M.; Upadhyaya, H.D.; Bisht, I.S. 5 Faba Bean. In Genetic and Genomic Resources of Grain Legume Improvement; Singh, M.; Upadhyaya, H.D.; Bisht, I.S. Elsevier: Oxford, UK, 2013; pp. 113-136. 
13. Köpke, U.; Nemecek, T. Ecological services of faba bean. Field Crops Res. 2010, 115, 217-233. [CrossRef]

14. Wilkins, R.J.; Jones, R. Alternative home-grown protein sources for ruminants in the United Kingdom. Anim. Feed Sci. Technol. 2000, 85, 23-32. [CrossRef]

15. Calabrò, S.; Cutrignelli, M.I.; Gonzalez, O.J.; Chiofalo, B.; Grossi, M.; Tudisco, R.; Panetta, C.; Infascelli, F. Meat quality of buffalo young bulls fed faba bean as protein source. Meat Sci. 2014, 96, 591-596. [CrossRef]

16. Schwarz, F.J.; Kirchgessner, M. Verfütterung von Samen verschiedener Leguminosen (Ackerbohne, Erbse, Lupine) und Rapsextraktionsschrot aus 0- und 00-Sorten in der Bullenmast. 1. Mitteilung: Zum Austausch von Sojaextraktionsschrot gegen alternative Eiweisskomponenten. Züchtungskunde 1989, 61, 71-82.

17. Zdunczyk, Z.; Minakowski, D.; Frejnagel, S.; Flis, M. Comparative study of the chemical composition and nutritional value of pumpkin seed cake, soybean meal and casein. Nahrung 1999, 43, 392-395. [CrossRef]

18. Antunović, Z.; Klir, Ž.; Šperanda, M.; Sičaja, V.; Čolović, D.; Mioč, B.; Novoselec, J. Partial replacement of soybean meal with pumpkin seed cake in lamb diets: Effects on carcass traits, haemato-chemical parameters and fatty acids in meat. S. Afr. J. Anim. Sci. 2018, 48, 695-704. [CrossRef]

19. Klir, Z.; Castro-Montoya, J.M.; Novoselec, J.; Molkentin, J.; Domacinovic, M.; Mioc, B.; Dickhoefer, U.; Antunovic, Z. Influence of pumpkin seed cake and extruded linseed on milk production and milk fatty acid profile in Alpine goats. Animal 2017, 11, 1772-1778. [CrossRef]

20. Wild, K.J.; Steingaß, H.; Rodehutscord, M. Variability in nutrient composition and in vitro crude protein digestibility of 16 microalgae products. J. Anim. Physiol. Anim. Nutr. 2018, 102, 1306-1319. [CrossRef]

21. Soni, R.A.; Sudhakar, K.; Rana, R.S. Spirulina-From growth to nutritional product: A review. Trends Food Sci. Tech. 2017, 69, 157-171. [CrossRef]

22. Nasr, J.; Komisar, J.; de Zeeuw, H. A panorama of rooftop agriculture types. In Rooftop Urban Agriculture; Orsini, F., Dubbeling, M., De Zeeuw, H., Gianquinto, G., Eds.; Springer: Cham, Switzerland, 2017; pp. 9-29.

23. Habib, M.A.B.; Parvin, M.; Huntington, T.C.; Hasan, M.R. Review on Culture, Production and Use of Spirulina as Food for Humans and Feeds for Domestic Animals and Fish; Food and Agriculture Organisation of the United Nations (FAO): Rome, Italy, 2008.

24. Van Krimpen, M.M.; Bikker, P.; Van der Meer, I.M.; Van der Peet-Schwering, C.M.C.; Vereijken, J.M. Cultivation, Processing and Nutritional Aspects for Pigs and Poultry of European Protein Sources as Alternatives for Imported Soybean Products; Wageningen UR Livestock Research: Lelystad, The Netherlands, 2013; p. 10.

25. Kulpys, J.; Paulauskas, E.; Pilipavičius, V.; Stankevičius, R. Influence of cyanobacteria Arthrospira (Spirulina) platensis biomass additives towards the body condition of lactation cows and biochemical milk indexes. Agron. Res. 2009, 7, 823-835.

26. Lamminen, M.; Halmemies-Beauchet-Filleau, A.; Kokkonen, T.; Jaakkola, S.; Vanhatalo, A. Different microalgae species as a substitutive protein feed for soya bean meal in grass silage based dairy cow diets. Anim. Feed Sci. Technol. 2019, 247, 112-126. [CrossRef]

27. Manzocchi, E.; Guggenbühl, B.; Kreuzer, M.; Giller, K. Effects of the substitution of soybean meal by spirulina in a hay-based diet for dairy cows on milk composition and sensory perception. J. Dairy Sci. 2020, 103, 11349-11362. [CrossRef]

28. Agroscope. Feeding Recommendations for Ruminants (in German). Available online: https://www.agroscope.admin.ch/ agroscope/de/home/services/dienste/futtermittel/fuetterungsempfehlungen-wiederkaeuer.html (accessed on 28 March 2021).

29. Proviande Genossenschaft. CH-TAX Einschätzungssystem für Schlachttiere und Schlachtkörper (Rindvieh, Schafe); Proviande Genossenschaft: Berne, Switzerland, 2015.

30. AOAC INTERNATIONAL. Official Methods of Analysis; Association of official analytical chemists: Arlington, VA, USA, 1997.

31. VDLUFA. Methodenbuch Vol. 3: Die Chemische Untersuchung von Futtermitteln; VDLUFA-Verlag: Darmstadt, Germany, 2012.

32. Licitra, G.; Hernandez, T.M.; Van Soest, P.J. Standardization of procedures for nitrogen fractionation of ruminant feeds. Anim. Feed Sci. Technol. 1996, 57, 347-358. [CrossRef]

33. Agroscope. Berechnungsprogramme. 2017. Available online: https://www.agroscope.admin.ch/agroscope/de/home/services/ dienste/futtermittel/berechnungsprogramme.html (accessed on 2 November 2020).

34. Hintz, H.F.; Heitman, H., Jr.; Weir, W.C.; Torell, D.T.; Meyer, J.H. Nutritive value of algae grown on sewage. J. Anim. Sci. 1966, 25, 675-681. [CrossRef]

35. Mueller, S.; Taddei, L.; Albiker, D.; Kreuzer, M.; Siegrist, M.; Messikommer, R.E.; Gangnat, I.D.M. Growth, carcass, and meat quality of 2 dual-purpose chickens and a layer hybrid grown for 67 or $84 \mathrm{D}$ compared with slow-growing broilers. J. Appl. Poult. Res. 2020, 29, 185-196. [CrossRef]

36. Honikel, K.O. Reference methods for the assessment of physical characteristics of meat. Meat Sci. 1998, 49, 447-457. [CrossRef]

37. Wolf, C.; Ulbrich, S.E.; Kreuzer, M.; Berard, J.; Giller, K. Differential partitioning of rumen-protected n-3 and n-6 fatty acids into muscles with different metabolism. Meat Sci. 2018, 137, 106-113. [CrossRef] [PubMed]

38. IUPAC. Preparation of the fatty acid methyl esters. In IUPAC Standard Methods for the Analysis of Oils, Fats and Derivates; Dieffenbacher, A., Pocklington, W.D., Eds.; Blackwell Scientific Publications: Oxford, UK, 1987; pp. $123-129$.

39. Ulbricht, T.L.V.; Southgate, D.A.T. Coronary heart disease: Seven dietary factors. Lancet 1991, 338, 985-992. [CrossRef]

40. Heuzé, V.; Tran, G.; Kaushik, S. Soybean Meal. Available online: https:/ / feedipedia.org/node/674 (accessed on 24 July 2020).

41. Makkar, H.P.S.; Becker, K.; Abel, H.; Pawelzik, E. Nutrient contents, rumen protein degradability and antinutritional factors in some colour- and white-flowering cultivars of Vicia faba beans. J. Sci Food Agric. 1997, 75, 511-520. [CrossRef] 
42. Aguilera, J.F.; Bustos, M.; Molina, E. The degradability of legume seed meals in the rumen: Effect of heat treatment. Anim. Feed Sci. Technol. 1992, 36, 101-112. [CrossRef]

43. Costa, D.F.A.; Quigley, S.P.; Isherwood, P.; McLennan, S.R.; Poppi, D.P. Supplementation of cattle fed tropical grasses with microalgae increases microbial protein production and average daily gain. J. Anim. Sci. 2016, 94, 2047-2058. [CrossRef] [PubMed]

44. Wild, K.J.; Steingaß, H.; Rodehutscord, M. Variability of in vitro ruminal fermentation and nutritional value of cell-disrupted and nondisrupted microalgae for ruminants. GCB Bioenergy 2019, 11, 345-359. [CrossRef]

45. Cutrignelli, M.I.; Piccolo, G.; Bovera, F.; Calabrò, S.; D’Urso, S.; Tudisco, R.; Infascelli, F. Effects of two protein sources and energy level of diet on the performance of young Marchigiana bulls. 1. Infra vitam performance and carcass quality. Ital. J. Anim. Sci. 2008, 7, 259-270. [CrossRef]

46. Puhakka, L.; Jaakkola, S.; Simpura, I.; Kokkonen, T.; Vanhatalo, A. Effects of replacing rapeseed meal with fava bean at 2 concentrate crude protein levels on feed intake, nutrient digestion, and milk production in cows fed grass silage-based diets. $J$. Dairy Sci. 2016, 99, 7993-8006. [CrossRef]

47. Lamminen, M.; Halmemies-Beauchet-Filleau, A.; Kokkonen, T.; Vanhatalo, A.; Jaakkola, S. The effect of partial substitution of rapeseed meal and faba beans by Spirulina platensis microalgae on milk production, nitrogen utilization, and amino acid metabolism of lactating dairy cows. J. Dairy Sci. 2019, 102, 7102-7117. [CrossRef] [PubMed]

48. Lamminen, M.; Halmemies-Beauchet-Filleau, A.; Kokkonen, T.; Simpura, I.; Jaakkola, S.; Vanhatalo, A. Comparison of microalgae and rapeseed meal as supplementary protein in the grass silage based nutrition of dairy cows. Anim. Feed Sci. Technol. 2017, 234, 295-311. [CrossRef]

49. Staerfl, S.M.; Soliva, C.R.; Leiber, F.; Kreuzer, M. Fatty acid profile and oxidative stability of the perirenal fat of bulls fattened on grass silage and maize silage supplemented with tannins, garlic, maca and lupines. Meat Sci. 2011, 89, 98-104. [CrossRef] [PubMed]

50. SUZUKI, A. Characteristics of Biceps femoris and Longissimus thoracis muscles of five cattle breeds grown in a feedlot system. Anim. Sci. J. 2003, 74, 59-65. [CrossRef]

51. Sami, A.S.; Augustini, C.; Schwarz, F.J. Effects of feeding intensity and time on feed on performance, carcass characteristics and meat quality of Simmental bulls. Meat Sci. 2004, 67, 195-201. [CrossRef] [PubMed]

52. Cutrignelli, M.I.; Calabrò, S.; Bovera, F.; Tudisco, R.; D’Urso, S.; Marchiello, M.; Piccolo, V.; Infascelli, F. Effects of two protein sources and energy level of diet on the performance of young Marchigiana bulls. 2. Meat quality. Ital. J. Anim. Sci. 2008, 7, 271-285. [CrossRef]

53. Li, X.; Babol, J.; Bredie, W.L.P.; Nielsen, B.; Tománková, J.; Lundström, K. A comparative study of beef quality after ageing longissimus muscle using a dry ageing bag, traditional dry ageing or vacuum package ageing. Meat Sci. 2014, 97, 433-442. [CrossRef]

54. Boakye, K.; Mittal, G.S. Changes in colour of beef m. longissimus dorsi muscle during ageing. Meat Sci. 1996, 42, 347-354. [CrossRef]

55. Li, Y.; Liu, S. Reducing lipid peroxidation for improving colour stability of beef and lamb: On-farm considerations. J. Sci. Food Agric. 2012, 92, 719-726. [CrossRef]

56. Marino, R.; Albenzio, M.; Braghieri, A.; Muscio, A.; Sevi, A. Organic farming: Effects of forage to concentrate ratio and ageing time on meat quality of Podolian young bulls. Livest. Sci. 2006, 102, 42-50. [CrossRef]

57. Monsón, F.; Sañudo, C.; Sierra, I. Influence of cattle breed and ageing time on textural meat quality. Meat Sci. 2004, 68, 595-602. [CrossRef]

58. O'Sullivan, A.; O'Sullivan, K.; Galvin, K.; Moloney, A.P.; Troy, D.J.; Kerry, J.P. Grass silage versus maize silage effects on retail packaged beef quality. J. Anim. Sci. 2002, 80, 1556-1563. [CrossRef] [PubMed]

59. Sami, A.S.; Schuster, M.; Schwarz, F.J. Performance, carcass characteristics and chemical composition of beef affected by lupine seed, rapeseed meal and soybean meal. J. Anim. Physiol. Anim. Nutr. 2010, 94, 465-473. [CrossRef] [PubMed]

60. Simopoulos, A.P. The importance of the ratio of omega-6/omega-3 essential fatty acids. Biomed. Pharmacother. 2002, 56, 365-379. [CrossRef]

61. Kashani, A.; Holman, B.W.B.; Nichols, P.D.; Malau-Aduli, A.E.O. Effect of Level of Spirulina Supplementation on the Fatty Acid Compositions of Adipose, Muscle, Heart, Kidney and Liver Tissues in Australian Dual-Purpose Lambs. Ann. Anim. Sci. 2015, 15, 945-960. [CrossRef] 